\title{
El rol de les protagonistes dels relats etnopoètics lligats a topònims de la Ribera d'Ebre, la Terra Alta i el Priorat
}

\author{
Sílvia Veà Vila \\ Universitat Rovira i Virgili \\ silvia.vea@urv.cat
}

RESUM

En aquest article es presenten I7 relats etnopoètics recollits a les comarques de la Ribera d'Ebre, la Terra Alta i el Priorat, a la demarcació de Tarragona (Catalunya). Aquests relats estan directament lligats a topònims d'aquesta zona geogràfica, de manera que molts expliquen l'origen dels noms d'accidents topogràfics, arbres i construccions, $i$ altres hi estan relacionats directament, perquè expliquen esdeveniments ocorreguts en aquests indrets.

La recollida dels materials etnopoètics ha estat a través d'entrevistes personals gravades $i$, després, transcrites seguint uns estàndards. Posteriorment, s'ha fet una anàlisi dels textos i s'ha observat que, majoritàriament, responen al patró de tradicions explicatives, $i$, en un cas, al d'un amonestament. Simultàniament, se n'ha fet una anàlisi des del punt de vista del gènere a partir dels rols que desenvolupen les protagonistes dels relats $i$ alguns altres personatges. Amb aquesta darrera anàlisi, s'ha pogut observar, en primer lloc, que la majoria dels rols de les dones que hi apareixen corresponen a bruixes, altres dones malvades i perilloses, dones passives el paper de les quals és la reproducció, dones víctimes d'agressions sexuals, prostitutes...; en segon lloc i darrer, només una petita minoria presenten protagonistes valentes, decidides i positives, i encara una part de les quals demostren aquesta valentia amb l'opció del suïcidi.

\section{PARAULES CLAU}

toponímia; llegenda; estudis de gènere; folklore; Ribera d'Ebre; Terra Alta; Priorat

\begin{abstract}
This article presents I7 ethnopoetic narratives collected in the Ribera d'Ebre, Terra Alta and Priorat areas of Tarragona (Catalonia). These narratives are directly linked to the place names of the area and explain in many cases the origins of the names of many features, trees, and buildings, while others are closely linked to these places because they tell of past events that occurred there.

The ethnopoetic material was collected through recorded interviews which have been transcribed in accordance with a specific standard. The texts were then analysed and classified according to established folklore patterns (narrative tradition, etc.). Simultaneously, a gender analysis was carried out by analysing the roles of the main female characters and other characters. This analysis showed that women were most commonly depicted as evil and dangerous, as passive, with the sole function of reproduction, as victims of sexual assault and harassment, as witches, as prostitutes, etc. Only a small minority of the stories depict brave, determined, positive female main characters, and even for some of these, the only way they have of demonstrating their bravery is by committing suicide.
\end{abstract}

KEYWORDS

Place names; legends; gender studies; folklore; Ribera d'Ebre; Terra Alta; Priorat

REBUT: I3-IO-2OI7 | ACCEPTAT: 23-IO-2OI7

Estudis de Literatura Oral Popular, núm. 6, 20I7, II7-I40 | DOI: Io.I7345/elop2OI7II7-I4O ISSN: 2OI4-7996 | http://revistes.urv.cat/index.php/elop 


\section{Introducció}

La recerca en el camp de l'onomàstica sovint condueix a la troballa de relats etnopoètics associats als topònims. En la majoria dels casos es tracta de tradicions explicatives en les quals s'intenta aclarir l'origen del nom de l'indret en qüestió o alguna de les seues característiques.

Un dels objectius de l'estudi de la toponímia és lingüístic, és l'afany per descobrir l'etimologia que s'amaga darrere de cada nom, per comprendre l'evolució de la llengua en el temps i per entendre el significat de la realitat que representen aquests noms. I aquesta tasca científica la fan experts. Això no obstant, aquest mateix afany ha existit sempre en l'ésser humà i no només els estudiosos han presentat hipòtesis en aquest sentit, sinó que la cultura popular sempre n'ha formulat, això sí, sobre unes bases ben diferents, que s'assenten sobre el coneixement de la realitat que l'envolta, els valors de la seua societat, la religió del moment, etc. (Mallorquí 2006: I27-I44).

I és en aquest punt que entronquen toponímia i folklore. Com diu Baldaquí (I997: 45), el llegendari és un dels camps on les relacions entre la toponímia i la literatura són més abundants i tenen una major difusió i funcionalitat socials, atès que les persones de totes les èpoques han tingut la necessitat d'explicar l'origen d'aspectes del món natural i, en especial, dels accidents topogràfics.

Aquest article no s'ha limitat a estudiar relats lligats només a accidents topogràfics, per bé que són els majoritaris, sinó que també ha pres en consideració altres topònims com ara els noms dels arbres o d'edificis singulars, com castells. A més, s'ha tancat encara una mica més el diafragma de l'objectiu per afegir-hi precisió i observar aquests relats des d'una perspectiva de gènere i veure els diferents rols que la cultura popular ha atorgat a les protagonistes d'aquests relats.

Jeana Jorgensen (2008) estableix tres nivells diferents per estudiar el folklore des d'una perspectiva de gènere. En primer lloc, parla d'un nivell textual, que estudia el contingut dels relats, els temes i els personatges principals que hi intervenen. En segon lloc, esmenta el nivell contextual, que se centra en les persones que fan de col-lectores o d'informants dels materials folklòrics. I, en tercer lloc, parla d'un nivell metatextual, que té a veure amb la manera que la variable gènere incideix en l'adaptació dels textos o en l'elaboració de versions transgressores que capgiren els rols dels personatges respecte als rols tradicionals de gènere. ${ }^{2}$ En aquest article es vol analitzar, sobretot, el nivell textual, per bé que en algun moment es fa un breu esment al nivell contextual.

El corpus estudiat està format, majoritàriament, per relats de protagonista femenina. Només en dos d'aquests el personatge femení té un paper secundari.

La zona geogràfica on s'ha dut a terme la investigació està composta per les comarques de la Ribera d'Ebre, la Terra Alta i el Priorat. S'han recollit relats de les poblacions següents de la comarca de la Ribera d'Ebre: Ascó, Móra d'Ebre, Tivissa,

\footnotetext{
I Aquest article s'emmarca en una línia de recerca sobre literatura popular catalana que ha rebut finançament del Ministeri d'Economia i Competitivitat a través del projecte d'R+D: FFI2OI5-64I28-P (MINECO/FEDER), i forma part de la investigació del Grup de Recerca Identitats en la Literatura Catalana (GRILC), consolidat per la Generalitat de Catalunya (2OI4 SGR 755).

2 Quant a aquesta temàtica, és avinent consultar l'article d'Oriol (2013).
} 
la Torre de l'Espanyol i Vinebre; 3 de la Terra Alta: Arnes, Bot, Gandesa i Horta de Sant Joan, i del Priorat: Cornudella de Montsant (Siurana) i Marçà.

El total de relats estudiats són I7, que, segons l'origen geogràfic, són els següents:

Ribera d'Ebre:

- Ascó: «La roca de les Bruixes»

- Móra d'Ebre: «La cova de la Porca», «Galbor d'Entença»,

- Rasquera: «Lo salt del Flare»

- Tivissa: «Miss Amaroi», «Les Cabreres», «La carrasca de Guixo» (2 versions molt semblants) $\mathrm{i}$ «El tormo de la Margarida»

- Vinebre: «La roca del Cap del Pla» (2 versions)

- La Torre de l'Espanyol: «La roca de la Bruixeta»

Terra Alta:

- Arnes: «La cova del Moro»

- Bot: «Lo forat de la Donzella»

- Gandesa: «La Serena de Pàndols»

- Horta de Sant Joan: «El baixador de la Mala Dona»4

Priorat:

- Cornudella de Montsant: «Lo salt de la Reina Mora» (Siurana)

- Marçà: «La Miloquera»

\section{Metodologia}

El corpus que s'ha utilitzat per confeccionar aquest article té diversos orígens. D'una banda, la majoria dels relats són fruit de la investigació de camp de l'autora, feta amb motiu d'aquest article. S'han cercat informants de diversos pobles de la Ribera d'Ebre, la Terra Alta i el Priorat i s'hi ha fet entrevistes enregistrades en àudio - la majoria - i altres en les quals s'ha pres nota escrita de la informació.

D'altra banda, un nombre menor de relats procedeixen de l'Arxiu de Folklore del Departament de Filologia Catalana de la Universitat Rovira i Virgili i han estat publicats o esmentats en l'obra El patrimoni oral a les comarques que Tarragona. Relats tradicionals, de Carme Oriol, amb la col-laboració de Txell Granados i Emili Samper, i publicada per la Diputació de Tarragona l'any 2005. En aquest cas, les referències i les dades dels informants consten en una nota a peu de pàgina.

Els informants han estat localitzats, bàsicament, mitjançant el boca-orella, per bé que altres vegades el contacte ha nascut del fet de trobar-ne informació per Internet $\mathrm{i}$ accedir-hi a posteriori mitjançant alguna persona coneguda. En tots els casos, s'ha parlat directament amb ells mitjançant una entrevista personal i presencial i, en algun cas aïllat, telefònica. Per comarques, els informants entrevistats han estat els següents:

3 I, a més, es fa referència a dos topònims de Flix i de Riba-roja d'Ebre.

4 També es anomenat el pujador de la Mala Dona. 
Ribera d'Ebre:

- Santi Alfonso Falcó. Nascut a Móra d'Ebre l'any I950. Hi ha viscut sempre. Va treballar en una impremta uns anys i ara és massatgista.

- Montse Bladé Bru. Nascuda a Tivissa l'any i959. És infermera. Sempre ha viscut a Tivissa.

- Pere Muñoz Hernández, nascut a Flix el I954, hi ha viscut sempre. Professor d'Història i Geografia i polític.

- Teresa Pellissa Benaiges, nascuda el I956 a Rasquera, hi ha viscut sempre. Cuinera, cambrera i pagesa.

- Josep Maria Pros Tarragó. Nascut a Vinebre el I949. Titulat universitari en Magisteri, però carnisser d'ofici. Sempre ha viscut a Vinebre.

- Joaquim Rosset Piñol. Nascut a Tivissa el I974, hi ha viscut sempre. Enginyer geòleg i regidor de l'Ajuntament.

- Mercè Veà Borràs. Nascuda l'any I958 a la Torre de l'Espanyol. Mestressa de casa. Als I8 anys va marxar a viure a Móra la Nova, i des de fa 35 anys viu a Móra d'Ebre.

\section{Terra Alta:}

- Francisco Badia Badia. Nascut el i95 a Horta de Sant Joan. Hi ha viscut sempre. Ha estat obrer i empresari de construcció.

- Antoni Cortés Manyà. Nascut a Bot el I95I. Hi ha viscut sempre. Ha fet de carnisser, de pastor i de pellaire, i ha treballat en un celler i en una fàbrica de plàstics i neteges.

- Rafel Jornet Escuder. Nascut a Gandesa el i944. Ha viscut sempre a Gandesa. Ha treballat en una empresa de maquinària. Marit de M. Espina Niella.

- M. Espina Niella Clua. Nascuda a Calaceit el I945. Mestressa de casa i botiguera. Viu a Gandesa des que es va casar. Muller de Rafel Jornet.

Priorat:

- Diana Domènech Rofes, nascuda a Marçà el I968. Hi ha viscut sempre, tret de I9 anys que va estar-se a Barcelona. Llicenciada en Filologia Romànica (especialitat Gallec i Portuguès), fa de professora de secundària.

En el cas de les entrevistes gravades en àudio, se n'ha fet la transcripció corresponent, algunes de les quals es reprodueixen en aquest article. En la transcripció s'ha respectat escrupolosament els trets dialectals fonètics, morfològics i sintàctics i, si ha escaigut, el lèxic foraster que hagi utilitzat l'informant. Cal advertir, a més, que s'han respectat les variacions individuals dels parlants. En els casos en què es presenta diàleg amb la col-lectora, s'han indicat els torns de conversa amb les inicials $I$ per a l'informant i $C$ per a la col-lectora. Els detalls i els conceptes que l'informant especifica a la col-lectora s'han posat entre parèntesis. I les anotacions d'aquesta darrera, entre claudàtors. Les petites pauses són indicades amb tres punts suspensius. Si hi ha algun fragment, dins de cada transcripció, que es refereix a temes que no tenen res a veure amb el discurs narratiu principal, no s'hi inclòs i s'ha assenyalat amb tres punts entre claudàtors.

Per contra, en els casos en què s'ha pres nota escrita de les entrevistes, no se'n presenta transcripció, sinó una explicació. 
En totes les entrevistes s'ha intentat que, a més del text, hi quedés palès el context en què s'utilitzava i la font de transmissió d'on l'informant l'ha rebut. S'han descartat les dades i les versions que no s'han obtingut mitjançant la transmissió oral intergeneracional.

\section{Anàlisi}

Com s'avançava en l'apartat d'introducció, la gran majoria dels relats recollits en aquesta investigació són tradicions explicatives, fet habitual en els relats lligats a topònims. De fet, només n'hi ha un que s'aparta d'aquesta classificació, ja que és un amonestament, «La Serena de Pàndols».

\subsection{Les tradicions explicatives}

Oriol (2002: 79) defineix les tradicions explicatives com aquelles que relaten l'origen d'algun tret del nostre món lligat, generalment, al llenguatge i que molts cops s'utilitzen per explicar l'origen de topònims o renoms. Entre els relats recollits per dur a terme aquest estudi, n'hi ha un gran nombre que, efectivament, expliquen el motiu del nom del topònim. Són els següents: «La roca de la Bruixeta, de la Torre de l'Espanyol; «La roca de les Bruixes», d'Ascó; «La Miloquera», de Marçà; «La cova de la Porca», de Móra d'Ebre; «Lo baixador de la Mala Dona», d'Horta de Sant Joan; «Lo forat de la Donzella», de Bot; «La cova del Moro», d'Arnes; «Lo salt del Flare», de Tivissa; «Miss Amaroi» $\mathrm{i}$ «El tormo de la Margarida», de Tivissa, $\mathrm{i}$ «Lo salt de la Reina Mora», de Siurana.

D'altra banda, en dos dels relats, «La roca del Cap del Pla», de Vinebre, i «Les Cabreres», de Tivissa, no se n'explica el nom, sinó les característiques dels accidents geogràfics.

Tot seguit, es distingeixen els relats que projecten una imatge negativa de la dona, els que en projecten una imatge passiva i els que en projecten una imatge positiva.

\subsubsection{Tradicions explicatives que projecten una imatge negativa de la dona}

Dins d'aquest apartat es presenten dos subapartats, un de dedicat al personatge de la bruixa, molt abundant en el corpus que es mostra, i un subapartat per als altres personatges que projecten una imatge negativa de la dona.

\subsubsection{Tradicions explicatives de bruixes}

El rol que assumeixen, aquí, les dones protagonistes implica una sèrie de característiques gens afalagadores, ja que la imatge que es té de la bruixa al nostre país, tal com explica Cels Gomis a la seua obra La bruixa catalana, és ben desagradable:

Per al nostre poble, la bruixa és quasi sempre una dona vella, de pell arrugada, de llavis prims i descolorits, d'ulls petits, enfonsats i ribetejats de vermell; de cabells blancs escassos i mal pentinats; de cos estrafet, de mans llargues, primes i en forma d'urpes, de vestit apedaçat i sabates a retaló; en una paraula, per a la vulgaritat del poble català, la bruixa, a més de vella, és pobra i repugnant i va esparracada (Gomis I996: 4I). 
I, és clar, la majoria de vegades, aquest personatge és femení; poques són les vegades que es parla de bruixots.

«La roca del Cap del Pla» $\mathrm{i}$ «La roca de la Bruixeta» fan referència al mateix topònim. Aquesta roca és una roca singular, de dimensions considerables -més de dos metres d'alçada i uns tres per tres d'amplada-, aïllada de manera curiosa al cim d'un turó que serveix de molló entre els termes de Vinebre i de la Torre de l'Espanyol. Es tracta d'una roca calcària, en forma de dau partit per la meitat, situada al capdamunt d'un turó al nord de la partida de terra anomenada los Plans, a l'indret anomenat Cap del Pla. A la vila de Vinebre l'anomenen la roca del Cap del Pla i, a la Torre de l’Espanyol, la roca de la Bruixeta (Veà 20I7: I23-I24).

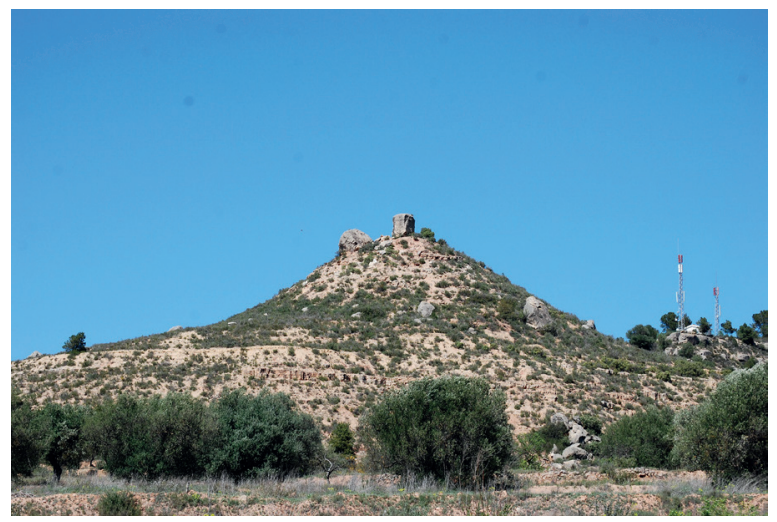

La roca del Cap del Pla o de la Bruixeta

S'han recollit 3 narracions explicatives que fan referència a l'origen de la roca. Es presenten tot seguit.

El relat recollit a la població de la Torre de l'Espanyol explica l'origen del nom que donen a la roca en aquesta vila.

Pos diuen que la gent de la Torre van deixar una campana als de Vinebre. I els de Vinebre no l'acabaven de tornar. Per més que la reclamessin, no l'acabaven de tornar. Cansats, ja, els de la Torre de que la campana no tornés, van contractar unes bruixes per a què destruissin lo campanar de Vinebre i puguer recuperar la campana. Les bruixes se'n van anar al Montsant i van agafar una pedra, la més grossa que van trobar. Se'n van anar cap a Vinebre disposades a tirar-la damunt del campanar. Però no comptaven que aquesta pedra que pesava tant... van calcular malament lo temps. Total que, quan passaven per damunt d'aquesta muntanyeta, va començar a sortir el sol, les bruixes van perdre la força i la pedra va caure just damunt de la muntanya. Per això es diu la Bruixeta. A la Torre, li diem la Bruixeta. ${ }^{5}$

En aquest relat, les bruixes es presenten amb força sobrehumana, capaces de fer mal i al servei d'aquells humans que els ho sol-licitin, sempre a canvi d'alguna cosa (les bruixes són contractades pels habitants de la Torre de l'Espanyol). L'únic

5 Informant: Mercè Veà, nascuda a la Torre de l'Espanyol l'any I958. Gravació feta al juliol de 2017 a Móra d'Ebre. 
defecte que tenen és la incapacitat de calcular bé el temps del trasllat de la pedra, fet que desencadena el naixement del topònim.

Els relats recollits a Vinebre no donen origen al topònim, però expliquen d'on prové la roca. La versió més extensa és la que ofereix l'informant Josep M. Pros de Vinebre, que explica:

Resulta que lo capellà de Vinebre va fer un sermó contra les bruixes, perquè diu que hi havie moltes bruixes que eren aliades del dimoni, i que la gent havie de lluitar, havien d'anar contra les bruixes. I a Vinebre n'hi havie quatre. I... i que no havien d'anar a les bruixes, i que s'havien de denunciar, i que... tothom contra les bruixes...

I les bruixes se van enfadar.

I van decidir anar a buscar una pedra molt gran al Montsant, perquè allí n'hi ha de molt grosses. I la baixarien una nit, quan tenien, quan tenien tot lo poder, la baixarien volant i la deixarien caure damunt de cal capellà i que l'empastrés. I sí, sí, dit i fet, la nit que va tocar van anar al Montsant i, bueno allí, uns pedregars. I va una i diu:

- Jo agafaria una llosa i així l'enxomarie tota la casa, bum!, de ple.

-No, dona, que és massa grossa. Una de punxeguda que es clavo i que ho destrosso tot.

L'altra:

-No, una com un dau gros, que l'empastro, ben... i que...

—No, que aquella és més... que aquella anirà més bé.

—Que no, que anirà més bé aquella altra...

I ja saps com són les dones, una detràs de l'altra, la seua opinió: «No, que tinc raó jo. Que tinc raó jo...». I es va fer tard.

-Correu, que si no, mos cantarà el gall i no hi serem a temps!

-Bueno, va, n'agafem una.

Una com un cub tremendo - encara la podem veure... bueno, la meitat, avui, se pot veure encara aquí a Vinebre, encara es pot veure lo grossa que era. Tenien molt poder, les bruixes per a portar la pedra esta del Montsant volant a la nit.

I la van anar a buscar, la van agafar entre les quatre i volaven, volaven, però havien perdut tant temps discutint lo volum i la forma de la pedra, que, quan estaven aquí al Cap del Pla, a prop de Vinebre, cante el gall. Ai, xiquet, quan van sentir cantar el gall, van perdre els poders, Se va.... van desaparèixer, se van tornar a transformar a baix a casa, però la pedra es va quedar allí i, clar, la llei de la gravetat: buuum, va caure. I no va caure damunt de cal capellà, va caure damunt del Cap del Pla i, del cop que es va pegar, es va partir. I tota la vida l'hem vist partida hasta fa uns quants anys, que la meitat encara hi és, però està... ha baixat. ${ }^{6}$

6 L'informant fa referència al fet que, a causa d'unes pluges insistents, una de les meitats de la pedra va perdre l'equilibri precari amb què s'aguantava i va desplaçar-se uns metres turó avall. 
I això és la llegenda7 de la roca del Cap del Pla, que a la Torre li diuen la Bruixeta. O sigue, que, és veritat, perquè si a la Torre diuen la Bruixeta és que bé eren les bruixes. ${ }^{8}$

En aquest relat, les protagonistes són quatre bruixes vinebranes que miren de venjar-se del capellà del poble, que les havia amenaçat. El topònim que resta a Vinebre no es relaciona amb el relat, sinó amb la partida de terra a la qual pertany: el Cap del Pla.

En aquesta narració, el rol que es dóna a les protagonistes és el d'aliada del dimoni i enemiga acèrrima de l'Església catòlica, dels seus administradors i dels seus adeptes, com proclama el capellà; per tant, aquests personatges són sentits com una amenaça. A més, s'atorga a les bruixes una sèrie de poders, els més destacables dels quals, segons aquest relat, són la capacitat de fer mal, la prodigiosa força que tenien i l'aptitud de volar, poders que els permet anar a buscar una gran roca a una distància considerable i endur-se-la volant amb la sola força de quatre individus.

A banda d'això, si es llegeix entre línies, en el text «La roca del Cap del Pla», es pot detectar una altra característica de les protagonistes que no va pas tan lligada al fet de ser bruixa i sí al fet de ser dona i que provoca que la missió de les protagonistes acabi en fracàs. Diu l'informant: «...i ja saps com són les dones, una darrere l'altra, la seua opinió» i aquest, "perdre el temps» en discussions, fa que se'ls faci de dia, perdin els poders i no puguin portar la pedra fins a l'abadia i escarmentar el capellà.

A la segona versió del relat, el paper de les bruixes dones tampoc no queda en gaire bon lloc:

La que m'explicaven a mi quan era petiteta. Hi havie la bruixa de la Torre, la bruixa de Vinebre, la bruixa de Flix i la bruixa d'Ascó, que resulta que van trobar un llençol de fil valuosíssim, que ja no es trobe; devie tindre unes filigranes... perquè es barallaven pel llençol. Llavòrens, cadascuna de les quatre estiraven una punta del llençol, estirant cap a casa seva, barallant-se i dient-se totes les males paraules del món. I, en estes, que van despertar el diable, que estave fent migdiada. I el diable es va empipar tant amb les punyeteres bruixes que no el deixaven dormir, que va anar, va agafar la pedra i patapam!, la va tirar damunt del llençol de fil i va quedar atrapat a sota i es van quedar sense llençol. I si hi voleu anar a veure-ho, encara es veu a sota. Aquesta és la que m'explicaven a mi (Oriol 2005: 2I).

En aquest relat la dona hi és vista com un ésser envejós i sorollós, i com una subalterna del dimoni, el qual pot manejar-la a voluntat sense gaire esforç.

La roca de les Bruixes d'Ascó es refereix a una roca situada a la falda de la muntanyeta del castell d'Ascó. I presenta unes bruixes que són ineptes, ja que calculen malament les seues forces i no són capaces de superar el repte que els habitants d'Ascó els plantegen perquè puguin romandre al poble.

7 Sovint, els informants utilitzen el mot «llegenda» per referir-se als relats que pertanyen a diversos gèneres etnopoètics.

8 Informant: Josep Maria Pros Tarragó. Nascut a Vinebre el I949. Relat recollit al juliol de 2017 a Vinebre. 
Així, doncs, segons s'explica, a Ascó hi havia tres germanes que eren bruixes. La gent les volia fer marxar del poble perquè temien els seus maleficis. Els van dir que si la nit de cap d'any, abans de tocar les dotze, pujaven unes roques a dalt del castell, els permetrien quedar-se al poble, però que en cas contrari haurien de marxar. Les bruixes ho van intentar, però com que el camí del castell feia molta pujada, es van cansar i les roques els van caure a sobre. Es creu que les bruixes són enterrades sota una d'aquestes roques, que es coneix amb el nom de la roca de les Bruixes (Oriol 2005: 22).9

També, dins de l'apartat dedicat a les bruixes, s'ha recollit la tradició explicativa de la muntanya de la Miloquera, a Marçà. La Miloquera és un turó situat al darrere del poble, molt proper, i és un lloc destacable per als seus habitants, que hi van a fer la berenada per Dijous Gras o qualsevol altre dia.

Lo nom de la Miloquera, la muntanya que tenim aquí a peu de poble i que anem sempre quan som... Bueno, quan som petits anàvem a fer-hi la berenada al Dijous Gras i qualsevol dia, però, bueno, sobretot lo Dijous Gras s'hi anava a fer la berenada i nàem fins la creu on se celebrava lo de la Via Crucis, doncs, nàem fins a la creu principal. Llavors, bueno, la Miloquera s'anomena així perquè ve de 'milos' i 'quera', que vol dir 'pedra embruixada' i mos deien que era perquè la nit de Sant Joan, doncs, les bruixes ballaven, així i feien una rotllana amb el foc al mig i.., d'alguna manera, també té el seu sentit perquè... pel tema de la foguera que celebrem per Sant Joan, i era la nit que recollien les plantes per a preparar les pòcimes. També té sentit perquè, per exemple, no ho sé, però, aquest any no hi he pogut anar, però fa dos anys he anat a... no aquí al Priorat, sinó a... no sé com se diu, a prop de Rasquera, ${ }^{\text {,o }}$ que hi ha aquelles valls i hi ha totes les ermites ... i hi anàvem precisament a collir plantes per a fer ratafia i tot just hi nàem, això, uns dies abans de Sant Joan. Bueno, jo t'ho explico més que res per això... doncs per què es diu Miloquera: recollien les plantes per a fer les pòcimes, tots els preparats que elles feien, no? [...] Segons m'havien dit sempre Miloquera volia dir milo-quera, que 'milo' ve de 'milos', exacte, és roca encantada, vale? Aquest és el significat." ${ }^{\text {II }}$

El lingüista Joan Coromines atribueix els noms 'miloca', 'miloquera', 'milocar', etc. a noms derivats de l'ocell de presa 'miloca' (Strix funerea i Otus vulgaris), com explica en DECat. v. 684. A més, Coromines explicita que «dels turons sobre els quals voleien o nien, en diuen una [miłu'kera] en molts pobles del Priorat (DECat. 684bi4)» (Coromines I994: 276).

Una altra narració lligada al rol femení de bruixa és «La carrasca de Guixo». Aquest arbre centenari de l'espècie Quercus ilex està situat a Tivissa, a uns 4 o 5 quilòmetres de la vila en direcció nord, a prop de la carretera que condueix de Tivissa als Guiamets, passant per la Serra d'Almos.

El text que es va recollir és el que es presenta tot seguit.

9 Relat recollit a l'Arxiu de Folklore de la URV: [ABG I5-96] per M. Amparo Baiges Gabaldà, 20 anys, Ascó (Ribera d'Ebre) I4-I2-96. Informant: Maria Gabaldà Màdico, mestressa de casa, 58 anys, Ascó (Ribera d'Ebre). Inclòs a la base de dades Arxiu Folk amb la referència $\mathrm{AF} 778 \mathrm{I}$.

Io Es refereix a Cardó.

II Informant: Diana Domènech Rofes, de Marçà. Relat recollit el 7 d'agost de 2017. 
I: També hi ha la llegenda de la carrasca de Guixo, que... conta la llegenda que en aquest arbre, que és mil.lenari, a les nits de... la nit del 30 d'abril, que és la de... la nit de les bruixes, pel solstici d'estiu, que és lo 24 de juny, i tots els solsticis de l'any, se trobaven, de tota la comarca, les dones remeieres que hi havia als pobles, les bruixes. I allà, pues, compartien los seus coneixements, pues...: «si poses més romer en un lloc, jo poso més mel». I es trobaven allà. S'engrescaven totes, es posaven a veure vi, s'animaven, ballaven, cantaven i era una trobada d'amigues. I ho feien varis cops a l'any.

Llavons, hi havia una noia de Tivissa i hi havia un pastor del poble que li anava al detràs. I, sí, es feien gràcia i tal. I al veure ell que «no puc sortir» o «ara estic ocupada». «No sé en què deu estar ocupada»... La va anar seguint, seguint, seguint... i se'n va donar compte que hi havia... cada tres o quatre mesos desapareixia. Una d'estes vegades la va seguir i va veure que anaven aquí a la carrasca de Guixo i que es trobaven totes i a ell li va semblar que allò era un aquelarre i devia veure jo què sé. I va anar a denunciar-la. Va dir «Si no ets per mi, no ets per ningú». La va denunciar i allavons les autoritats que hi havia del poble... ell va dir qui eren totes les que hi havia, les van apressar i les van portar a l'arbre aquest. I van dir que reneguessen del dimoni, i elles van dir que elles amb lo dimoni no hi tenien res. Que sí, que sí, que no, que no... una d'elles va dir que sí, perquè l'havien torturat i van agafar i les van penjar totes de l'arbre: «Lo vostre amo que us alliberi» ... Clar, lo dimoni no va vindre. Les van penjar, van morir penjades a l'arbre, a la carrasca de Guixo. I la d'aquí el poble va dir: «Esteu maleïts de per vida i aquest arbre, ja hi pot haver foc, que protegirà sempre la gent, que és lo que hem fet naltros. No es cremarà mai».

I fins al dia d'avui ha sigut així.

C: I hi ha hagut alguns incendis importants aquí a Tivissa...

I: Hi ha hagut alguns incendis. Fa quatre anys, n'hi va haver un de molt sèrio, allí, eh? Si vols t'hi porto en cotxe i ja veuràs com està tot del tombant... i ara ja hi ha crescut vegetació, però la carrasca no es va cremar. Res. ${ }^{\text {I2 }}$

En aquest relat es presenten les protagonistes com a remeieres incompreses, titllades de bruixes, traïdes per la resposta venjativa d'un home davant del rebuig d'una d'aquestes dones, en forma de denúncia. Finalment, aquestes dones acaben morint com a víctimes de l'autoritat civil i/o religiosa de la vila. Tanmateix, guarden amb elles algun dels poders atribuïts a les bruixes, i maleeixen els descendents d'aquella gent, però, d'altra banda, protegeixen la natura en la figura de l'alzina on són penjades com a càstig a la seua diferència. És un altre cas en què el rol de la dona és negatiu, per ser descrita com una bruixa, capaç de fer mal; però, per altra banda, també és capaç de fer el bé, protegint la carrasca. A més, i més important, la narradora explica la història de manera que s'evidencia una injustícia flagrant comesa contra aquelles dones.

I2 Informant: Montse Bladé, nascuda a Tivissa l'any I959. Relat recollit l'ıı de juliol de 20I7, a Tivissa. 


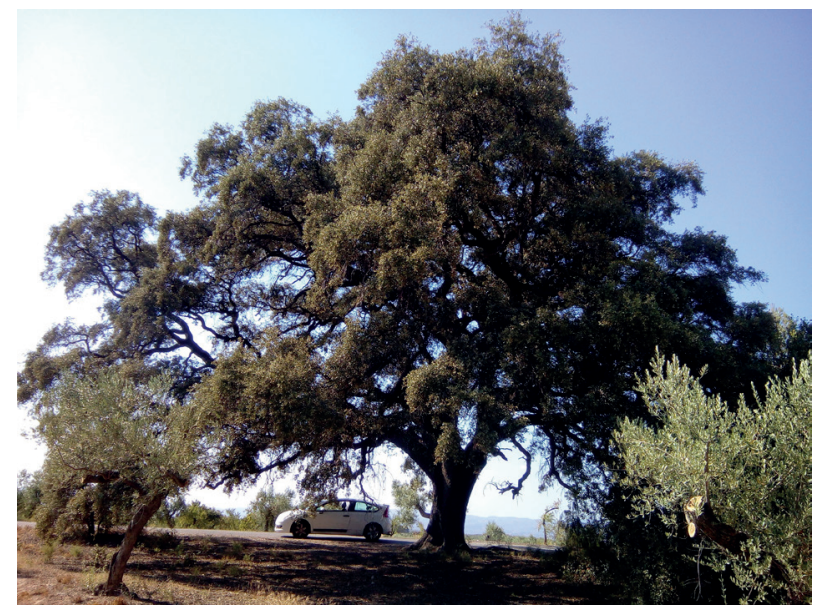

La carrasca de Guixo

És molt interessant, des del punt de vista de gènere, veure una altra de les versions recollides de «La carrasca de Guixo», l'informant de la qual és un home, ja que hi ha certes variacions:

Aquí al poble hi ha una carrasca de... bueno... monumental que se li diu la carrasca de Guixo. Conta la llegenda que aquest era un dels punts - no és l'únic... - , un dels punts on les bruixes del poble s'hi trobaven. En concret, s'hi trobaven dos nits: la nit del 30 d'abril, la nit de les bruixes, i el solstici d'istiu, per Sant Joan.

Un pastor del poble estava enamorat d'una d'elles. I una nit del 30 d'abril, la va seguir fins a la carrasca i quan va estar... quan ella arriba allà a la carrasca, pues ell se va amagar detràs d'unes herbes, d'un arbust, i va observar que realment doncs que sí, ell es pensava que era una bruixa i sí, sí, era una bruixa perquè allí va veure que s'hi va trobar amb altres bruixes. Va ser tal lo seu disgust que va anar cap a l'Ajuntament i li va comentar a l'alcalde. De seguit, després de que li expliquessin això, les forces públiques del poble, pues, anaven cada nit en aquella carrasca a verem si les bruixes s'hi trobaven per, bueno, per poder actuar. I hi anaven cada nit, cada nit i no les trobaven, fins que va arribar Sant Joan (recordem que ell la va seguir el dia 30 d'abril). I, bé, arriben a Sant Joan i, quan arriben a l'alçada de la carrasca, van sentir molt soroll. Se van quedat tots, tots, totes les forces públiques i el pastor, tots, amagats allí i van observar que realment feien... Lo que van veure va ser que totes aquelles noies, o sigui aquelles bruixes, se bevien un brevatge fet amb una cassola i que els hi feia perdre l'oremus. O sigui, les embogia directament. Quan van veure que estaven totes embogides i que estaven dansant al voltant de l'arbre, el que van fer va ser... agafar-les totes i les van penjar a totes les rames de l'arbre, de la carrasca, per així, eliminar-les.

Bé, doncs, conta la llegenda que des d'aquell dia, des de que va passar aquest fet, l'arbre ha continuat creixent i que, realment, no ha patit mai cap mal. Cap llamp, cap tronada... últimament, l'any 2015 vam tindre 
(l'any 2014 o 20I5, ara no me'n recordo exactament), vam tindre un incendi en aquella zona i la carrasca es va salvar (també s'ha de dir que els bomberos estaven justament en aquella zona). I bé, doncs, diuen que no li ha passat mai res perquè les bruixes la protegeixen. A més, a més, també es diu que els poders curatius que tenien les bruixes van passar a l'arbre i que si tu t'hi abraces allà, notes com aquests poders curatius t'acaben resolent lo teu dolor. I res més, aquesta és la llegenda de les bruixes de la carrasca de Guixo. ${ }^{13}$

El relat explica, d'entrada, que la carrasca era el punt de trobada de les bruixes (no pas remeieres) del terme i que s'hi prenien un beuratge durant tota la nit que els feia perdre l'oremus i les feia ballar al voltant de l'alzina. Després, explica que un pastor se'n va enamorar d'una i, en adonar-se que eren bruixes - l'estimada i les seues companyes-, disgustat, ho va comunicar (no pas denunciar, el matís és important) a l'alcalde de la població. La nit de Sant Joan les van vigilar, i les van agafar i les van penjar a la carrasca. Una altra petita diferència amb la versió de la informant és que la carrasca, des d'aleshores, no ha patit cap mal, i la informant insisteix que s'ha salvat de totes les tronades (fenomen meteorològic l'origen del qual és atribuït, tradicionalment, a les bruixes), per bé que també dels incendis. Finalment, afegeix que els poders curatius atribuits a les bruixes van passar a l'alzina i, si t'abraces al tronc i tens algun dolor, l'arbre et cura. Aquest detall és important, perquè reforça la idea que les bruixes devien ser remeieres, ja que no guareixen pas desinteressadament i amb la intenció de fer un bé.

Tot i que la mostra —una sola informant i un sol informant- no és suficient per fer grans extrapolacions, es podrien lligar aquestes diferències en el relat amb la tesi de James M. Taggart que esmenta Oriol (2013: I99) i que es relaciona amb el gènere dels informants: «posa de manifest que el gènere dels informants modula l'argument de la narració i el rol que hi tenen els personatges principals d'aquestes narracions. Així, les versions d'una mateixa rondalla poden resultar més feminitzades o més masculinitzades segons quin sigui el gènere dels narradors i de les seves audiències». Evidentment, aquest argument aplicable a les rondalles bé pot estendre's al cas de les tradicions explicatives i altres relats etnopoètics.

Finalment, i per tancar el capítol dedicat al paper de la bruixa, es volen esmentar dos topònims més que no duen un relat associat, però que són testimonis del que afirma Cels Gomis, «amb prou feines existeix cap poble a Catalunya on no hi hagi una bruixa o més [...] Poques són les contrades on no hi ha un gorg, una cova, una plana, un turó, un puig que no porti el terrorífic nom de les bruixes» (Gomis I996: 4I).

En primer lloc, s'ha tingut coneixement de la cova de les Bruixes de Riba-roja d'Ebre, situada a la dreta de l'Ebre, prop de la partida Matitxal, a I, $5 \mathrm{~km}$ del poble, de la qual s'explica que: «Diu la llegenda que allí es vestien les bruixes» (Cabré I974: 33). Aquesta és una cova de pissarra i esquistos, materials rars al terme, en el qual la pedra calcària, l'argila i el guix ho envaeixen tot. Potser aquesta singularitat va fer pensar els habitants de Riba-roja d'Ebre en fets i personatges sobrehumans. No deixa de ser curiós el fet que s'afirmi que les bruixes s'hi vestien, quan la tradició majoritària a Catalunya era just la contrària, que es despullessin per marxar pel fumeral i poder entrar a les cases pel forat del pany (Gomis I996: 46).

I3 Informant: Joaquim Roset Piñol, nascut a Tivissa el I974. Relat recollit l'agost de 20I7. 
I, en segon lloc, s'ha localitzat a Flix el carreró de les Bruixes, possible testimoni de la cacera de bruixes que va esdevenir a Catalunya al segle xvI, segons l'informant. ${ }^{I 4}$ El carreró de les Bruixes està situat entre l'actual carrer de les Tendes i el carrer del Caporal Rius, al bell mig del nucli antic de la vila.

\subsubsection{Tradicions explicatives amb altres personatges}

Continuant amb les tradicions explicatives que presenten una visió negativa de la figura femenina, hi ha la de la cova de la Porca, de Móra d'Ebre. ${ }^{15}$

I: La cova de la Porca és una petita cavitat que suposo que al seu temps rajava més aigua.

C: Ah! Rage aigua. On està situada?

I: Està situada a la falda mateix de la Picossa. La Picossa és la muntanya de... emblemàtica de... no és el punt més alt de la Cubeta de Móra, lo punt més alt està a Rasquera, però sí que és la més emblemàtica per la forma que té, perquè es veu des de molt lluny. Se veu també de la Terra Alta. I, aleshores, a la mateixa falda, en un sistema semirocós que hi ha, hi ha una cavitat (no és una cova llarga, eh? És una cova curta...)

C: Com una bauma...

I: Sí. Al seu voltant sí que hi ha cavitats molt fondes, però ella en si és una cavitat petita que hi goteja aigua. Com que és un lloc obert, que és balma, no s'han fet mai ni estalactites ni estalagmites, ni res, però, ara ho desconec, ja fa temps que no hi haig estat i amb la sequera que hi ha pos... suposo que no. Es va fer més típica la seva... el seu nom, sobretot a principis del segle passat, pel fet que constituïa un dels llocs on s'havia d'anar el dia de la romeria. La punta de la Picossa i la cova de la Porca constituïen un itinerari que, pels nostres besavis, era normal que anessin. Les noies anaven davant. I els nois darrere perquè així vèiem algo de cuixa. Pel jovent constituïa això.

[...]

El nom. Hi ha moltes versions. Sembla ser que molts s'apropen a que va ser refugi d'una dona de mala vida. Jo tinc la meva versió. La meva versió és que el fet de gotejar aigua molt sovint, feia que el terra fos molt lliscós, molt porc. Com que és cova, és dona. El demés està posat en la inventiva de la persona, que si s'hi va refugiar una dona, que si això, que si era bruixa, que si no era bruixa. No hi ha res escrit; per tant, cada $u$ pot fer la seva interpretació.

C: I què diu la gent? Què n'expliquen aquestes diferents veus?

I: Expliquen la seva versió, però tampoc mai ningú, al menos als grans que jo haig pogut parlar, tenen coneixement de cap dona que es refugiés allí. Implica més la picaresca que pas la veritat o la mentida. Cada u hi fa la seva versió igual que jo haig fet la meva. La possibilitat que algú es refugiés allí, de pujar per les roques per entrar en aquella petita cavitat, moltes vegades plena d'esbarzers i altres vegades, plena d'excrements de raboses i tal que s'hi van a refugiar o a beure o a llepar l'aigua, feia que aquell lloc

I4 Pere Muñoz Hernández, de Flix, nascut el I954.

I5 Explicada per Santi Alfonso Falcó, el 23 d'agost de 20I7, a l'Aubadera de Móra d'Ebre. 
fos més quadra que una altra cosa. Com als llocs que hi ha una mica d'humitat, passe la figuera... un arbre que deixa caure tota mena de porqueria.

$[\ldots]$

I: Aleshores, prop d'allí hi ha una altra roca que és la bifurcació de camins que va a unes finques que ja estan al terme de Garcia, i l'altre camí que va a Sant Jeroni, que es diu la roca Rodona. Per tant, l'adoració, diguem-ne a la natura, a les roques, precisament, la tenim, al principi en la roca Redona, la cova de la Porca i la Picossa. O sigui, fan un triangle de roques.

[...] És una cova petita que, si ho mirem bé, tampoc podia ser de massa refugi per a qualsevol persona, per a una dona tampoc; per tant, el nom tira més al fet «porc» del lloc que pas al fet que una dona de mala vida fes cap a ella.

C: Però tot i així, hi ha molta gent que creu que va per aquí, a una dona de mala vida que s'hi va refugiar.

I: No hem d'olvidar, Sílvia, que els nostres grans feien servir molt més la picaresca que ara...

Quant a aquest topònim, doncs, la veu popular n'explica el nom pel fet que en temps immemorials va estar habitada per una dona de mala vida que s'hi va retirar. Per tant, amb aquest topònim s'hi torna a trobar un rol negatiu per a una protagonista, el rol de prostituta.

El darrer relat que parla d'una dona amb atributs de dolenteria és més aviat curiós, es tracta d' «El pujador de la Mala Dona», a Horta de Sant Joan. En aquesta població de la Terra Alta s'anomena pujador (i, de vegades, baixador) un lloc rocós que condueix a un lloc a més altitud i es diferencia, per exemple, de la senda, que és un caminet que normalment va bastant planer. L'informant ${ }^{\mathrm{I} 6}$ explica que està situat damunt del mas del Lloar, al camí de Paüls, damunt del Ventador, que és un lloc on, actualment, es va a fer esports com el barranquisme, ja que, si se segueix més amunt del pujador, s'arriba a la Barca, una zona propera al riu Canaletes. I ens relata només el record d'un home que hi va estimbar la seua dona, però, a causa d'aquest fet, estranyament, ella no va prendre cap mal. ${ }^{17}$ En aquesta tradició explicativa es fa difícil interpretar el perquè de l'apel-latiu "mala dona», atès que la dona fou víctima de l'acció del seu marit i no pas a l'inrevés. Es podria especular que la raó que la dona no rebés lesions fos que tingués poders satànics i es tractés d'una bruixa, però no s'ha trobat cap informació que ho confirmi.

\subsubsection{Tradicions explicatives que projecten una imatge passiva de la dona}

Hi ha un subconjunt de tradicions explicatives que no presenten un rol negatiu actiu i explícit dels personatges femenins, però sí que els atorguen un rol passiu i destinat, bàsicament, a la reproducció de l'espècie, com és el cas de les Cabreres. El topònim les Cabreres anomena dos pics muntanyosos, bessons, del terme de Tivissa que es poden observar des d'una molt bona perspectiva des del jaciment ibèric del Castellet de Banyoles. El relat, per explicar l'origen d'aquesta duplicitat de cims, conta el següent:

I6 Francisco Badia Badia, d'Horta de Sant Joan. Entrevista feta a inicis de setembre de 2017. I7 Una versió més explícita es pot trobar a Oriol (2005: 30). 
I: Llavons, un dels cabdills del poble ${ }^{\mathrm{I} 8}$ es va casar amb una noia que era del poblat del Perelló. La noia s'enyorava de casa... parlaven diferent, perquè ni que fossin tots de la mateixa ètnia, ilercavons, no era prou igual. No es quedava embarassada, no es quedava embarassada, el cabdill volia un hereu i «com ho farem?», perquè per anar al poble no era com ara, que agafes lo cotxe i ja hi ets... I va decidir que els soldats del poble excavessin la roca i que al solstici de primavera i de tardor entrés lo sol per allí. Lo de primavera coincidia amb les festes del poble de la noia i, així, ella sempre sabria que al seu poble feien festa, i ells també en farien. Llavons, hi ha una muntanya que es diu les Cabreres, que estan tallades pel mig (geològicament, normal) i diu que això ho van fer els ibers. I si tu vas al poblat ibèric al solstici de primavera i al de tardor, lo sol sempre surt per allà al mig. Ho tinc comprovat, eh? Lo sol surt per allà al mig.

C: Pel mig de les Cabreres?

I: Sí, i allavons ella ja sabia que al seu poble feien festa, també en feien aquí i, al primer solstici, va donar la casualitat, se va quedar embarassada. Aquesta és la història. ${ }^{19}$

La muller del cabdill és un personatge feble, enyoradís, i, a causa d'això, no es queda embarassada i no assegura la transmissió de poder del seu marit. El cabdill pren el paper actiu i resol fer «moure muntanyes» perquè la seua dona trobi consol i li doni un hereu.

Es pot dir que aquest relat també té un component, en certa manera, meravellós, quant a les capacitats de la civilització ibèrica, molt implantada en el territori objecte d'estudi; la caracteritza com prou forta i d'enginyeria prou desenvolupada perquè un sol poblat arribés a poder partir una muntanya en dos.

Continuant en la línia de la reproducció humana, es fa referència al forat de la Donzella, que no té un relat associat, tret del fet que alguns dels habitants de Bot expliquen que el nom li ve de quan s'hi va refugiar una donzella que fugia dels moros.

Aquest forat, del qual brolla aigua de manera intermitent, està situat a pocs quilòmetres de la població, al peu del turó on hi ha l'ermita de sant Josep, a la vall per on passa el barranc del Mig i on es va fer una presa en temps de la darrera República espanyola. Actualment, la zona està condicionada amb unes taules i seients i una font d'aigua no tractada que prové del Forat.

Explica l'informant que, de vegades, en brolla un rajolí d'aigua prim com un dit i que, d'altres, en surt, de manera sobtada, un raig com el cos d'una persona adulta. El cabal depèn de la climatologia i, en general, n'hi ha quan es produeixen pluges constants; però, de vegades, també raja quan no plou gens a Bot. En aquests darrers casos, el doll d'aigua és precedit d'un fort soroll. El que l'informant mira de transmetre amb insistència és la fascinació de la gent del poble per aquell indret no només quan el forat brolla amb intensitat, sinó també d'altres vegades, en què, en paraules seues:

I8 Es refereix al poblat ibèric del Castellet de Banyoles.

I9 Informant: Montse Bladé Bru, nascuda a Tivissa el I959. Relat recollit el dia II de juliol de 2017 , a Tivissa. 
Busquem no-sé-què màgic. Busquem no-sé-què d'extraordinari. I jo sóc lo primer. T'ho dic perquè este sentiment també l'haig passat. I, home, vindre al Forat, mira si l'hem vist rajar vegades, però quan està plovent i surt, quan un o altre diu: Ha sortit lo Forat...! La gent en paraigües plovent... està com a festes majors. Sí, i és per l'atracció que tenim pel Forat. No sabem per què... Aviam, lo tenim com una cosa fantàstica però no sabem per què. ${ }^{20}$

També, al llarg de l'entrevista, l'informant explica que, de vegades, hi ha qui associa el personatge de la donzella amb una fada, afirmació que ens pot fer pensar en les goges o dones d'aigua.

En qualsevol cas, el que és evident és que l'explicació popular de la donzella que s'hi va refugiar no és coherent amb la mida del forat, en el qual una persona difícilment podria encabir-se, i pot interpretar-se, en canvi, com una manera de velar el que realment va motivar-ne el nom, ja que la seua forma s'assembla, prodigiosament, a la dels genitals femenins, com es pot observar en la fotografia il.lustrativa.

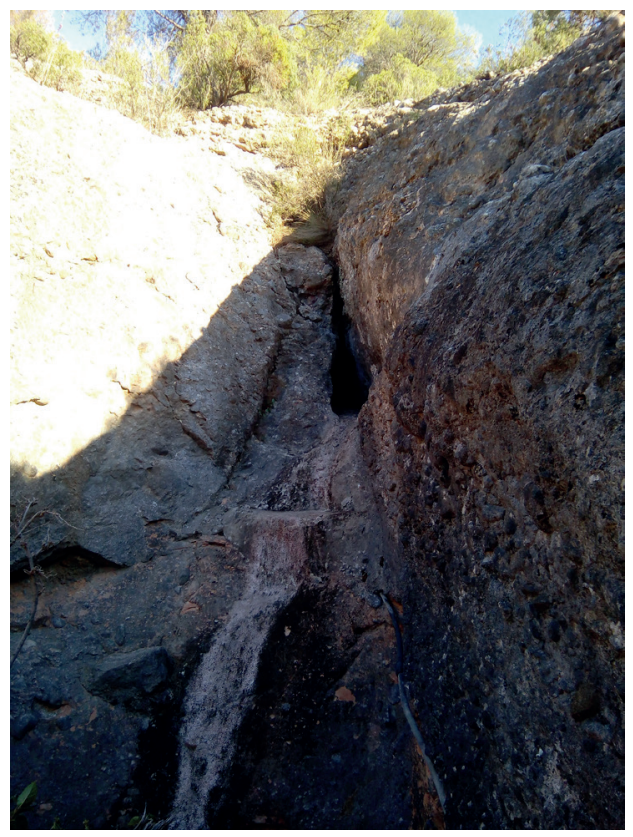

El forat de la Donzella

\subsubsection{Tradicions explicatives que projecten una imatge positiva de la dona}

Es tractaran, tot seguit, les tradicions explicatives que, a diferència de les anteriors, donen una imatge positiva de les protagonistes. Una de les que més topònims implica és «Miss Amaroi», de Tivissa, ja que explica els noms d'una partida

20 Informant: Antoni Cortés Manyà, de Bot, nascut el I95I. Informació recollida el 22 d'agost de 2017 al forat de la Donzella, Bot. Antoni Cortés és un activista cultural autodidacta que va publicar una narració força lluïda amb el nom «La Donzella del Forat». 
de terra (Missamaroi), d'unes cadolles (los clots d'Amantdell) i d'una font (la font de Missamaroi). A més, inclou altres topònims, com el morral de Pena-roja. Tots situats a ponent del terme de Tivissa, entre Càrcoles i el coll del Ventall.

I: La Missamaroi ${ }^{21}$ és una partida d'aquí del poble. Hi ha fonts amb aigua, arbres, al mig hi ha tot de roca, de sortir allà al mig, surt això. Conta la llegenda que cap allà el I82o un lord anglès va vindre (que s'havia quedat viudo), va vindre amb la filla, amb tots los criats. I la filla va descobrir la font i s'hi anava a banyar cada dia. Un del sèquit d'ella es va enam..., del seu pare, un criat, es va enamorar d'esta noia. Era jove, feia calor, es van trobar a la font i molt bé. Hi anava cada dia.

Tenien una minyona que es deia Amantdell, que la cuidava, a la noia, preparava el senyor, el menjar i li feia de dama de companyia. Allavòrens, el pare, un dia, passejant, la va veure a ella, que es banyava despullada i se li va girar el cap i... com si fos la seua dona, però... se li va tirar al damunt i la va voler violar. L'Amantdell va defensar la noia, perquè era la seua obligació i va deixar el pare malferit. Lo noi del sèquit també les va ajudar i van escapar com van poder, mig vestida, mig despullada.

Lo pare els va maleir i els va perseguir perquè els volia matar. Van arribar fins al morroi de Pena-roja -que és on se lliga la història-i, allí, la bruixa... perquè l'Amantdell era una bruixa, tenia poders, va maleir el lord, va obrir la muntanya i va fer que la noia i el noi entressen tots dins, amb lo sèquit. I, quan lo pare va voler entrar, no va poder entrar. I es va quedar picant a la roca. I va quedar boig. No va retornar mai més, esperant que sortissin la filla i demanant perdó, perquè, después, se'n va donar compte del que havia fet, però no va sortir mai més.

Allavons, se diu que les nits de lluna plena, si puges a Pena-roja i escoltes, sents com canten i riuen dins de la roca. Que, per sempre més, estaran dins feliços. I la bruixa surt de tant en tant. La bruixa surt.

C: L'Amantdell?

I: L'Amantdell. I surt a donar un vistasset, però com que deu veure que el món està molt malament, se n'entorna cap dins. Això és, en resum, la història. ${ }^{22}$

Aquest bell relat presenta uns personatges sotmesos a les passions de l'amor i el sexe, que confegeixen una història amb un final feliç gràcies a l'acció d'un personatge amb poders sobrehumans, una mena de bruixa bona. Presenta la innocència d'una jove que és agredida (Miss Amaroi), la pèrdua de cordura d'un home (el lord, pare de l'agredida) i el poder i la perspicàcia de la suposada bruixa que salva la víctima (Amantdell). ${ }^{23}$

2I Explica la informant que el nom de la partida, Missamaroi, és el nom de la filla del lord: Miss Amaroi. I que, curiosament, no sonoritzen l'alveolar fricativa i pronuncien ['misama'roj]. L'alveolar fricativa és al final de la paraula 'Miss' i, com que va seguida d'una vocal, caldria que sonoritzés i s'hauria de pronunciar ['mizama'roj]. Això pot indicar que el parlant no és conscient de l'origen del nom de la partida, que no l'identifica amb el tractament, Miss, seguit del nom de dona, Amaroi.

22 Informant: Montse Bladé Bru. Relat recollit el dia II de juliol de 20I7, a Tivissa.

23 Un altre dels informants, Joaquim Roset, de Tivissa, afirma que la filla del noble s'anomena Amantdell i la serventa Miss Amaroi. 
Aquí, els rols que s'adjudiquen a les dones protagonistes són ben diferents del cas dels relats de bruixes que s'han comentat adés. D'una banda hi ha una víctima, la filla del lord, Amantdell, jove, innocent i pura, trets, tots ells, positius d'entrada. I, de l'altra, hi ha l'heroïna, valenta, decidida i salvadora de la víctima, Miss Amaroi.

El fet que la informant digui que Miss Amaroi era bruixa no ha de prendre's com una cosa negativa, ja que ella té un concepte positiu de les bruixes remeieres. A més, segurament la identifica amb aquest rol perquè l'heroïna té poders extraordinaris, com el fet de poder obrir una roca i fer-hi entrar una colla de gent.

Si es continua estirant el fil del rol de víctimes de l'atac sexual que apareixen en altres relats recollits, s'observa que no tenen la sort de Miss Amaroi. Són les dones que apareixen a les llegendes de «La cova del Moro», d'Arnes, i «Lo salt del Flare», de Rasquera. Aquestes també són narracions explicatives de l'origen dels topònims on se situen, per bé que els noms són presos dels agressors masculins, un frare i un mahometà.

El relat «La cova del Moro» és extret de El patrimoni oral a les comarques de Tarragona. Relats tradicionals (Oriol 2005:26) i explica el segrest d'una dona de Beseit a mans d'un musulmà. La dona va ser obligada a viure en una cova que és al terme d'Arnes i l'entrada de la qual està a uns vint-i-cinc metres del terra, de manera que l'accés és gairebé impossible. La dona va ser forçada pel segrestador i, fins i tot, van tenir fills. Finalment, després d'uns anys de calvari, és alliberada per uns seus germans que mai no havien deixat de buscar-la.

El cas de «El salt del Flare» encara és més cruel amb les dones. L'indret és un penya-segat de la serra de Cardó. Segons la informant, ${ }^{24}$ l'espadat pren el nom del fet que es diu que els frares del monestir de Cardó s'allitaven amb monges i, quan quedaven embarassades, les llançaven de dalt baix d'aquest cingle per desfer-se del problema. Si tot plegat es va arribar a saber, va ser perquè els pares d'una de les monges joves van anar a buscar-la per treure-la del convent i no hi era. Arran de les investigacions, es va destapar tot el fet. El més esfereïdor és que la informant també explica que al peu del penya-segat s'hi han trobat ossets petits. ${ }^{25}$

Un altra tradició explicativa és «El tormo de la Margarida», la qual narra una història d'amor impossible entre jóvens que acaba en tragèdia, com Romeu i Julieta de Shakespeare. Lo tormo de la Margarida, com el seu genèric indica, és un penyal isolat. Està situat a la serra anomenada la Llena, força a prop de la població. El relat recollit és el següent:

I: La del Tormo de la Margarida és: aquí a Tivissa hi havia tres barris. Lo cristià, que estava dins al castell, dins dels murs; i extramurs hi havia el barri àrab i el barri jueu. Les fonts eren comunes i anaven a buscar aigua tots junts.

Hi havia una noia cristiana, que es deia Margarida, i es va enamorar d'un noi que es deia Alí, que era àrab. Clar, les famílies no ho volien, no

\footnotetext{
24 Teresa Pellissa Benaiges, de Rasquera. Entrevista feta a principis de setembre de 2017.

25 Aquest relat té altres versions. La mateixa informant n'explica una que diu que a Cardó hi havia dotze ermites amb ermità (flares) i cada ermita donava una de les hores del dia. Un dia n'hi va haver una que no va donar l'hora (perquè el flare es va adormir o perquè «estava amb una pastoreta») i, com a conseqüència, o el van llençar per l'espadat o s'hi va llançar ell. Una altra versió, on la víctima és un frare, es pot consultar a Oriol (2005: 40).
} 
estava ben vist. Llavons, van decidir que la Margarida es casés amb un senyor de dins del p... de Tivissa. I ella, desesperada, que és que no el volia per a res, van decidir fugir amb aquest noi. «I ara on anirem?»

Van pujar per un barrancó, tirant cap dalt a la Llena, los hi va sortir una tormenta i no sabien on anar. I van decidir matar-se els dos per amor, perquè ni ell per una altra ni ella per a un altre. I el tormo de la Margarida és una roca gran que hi ha i depèn del lloc que et posos la melena d'una noia estesa, amb la forma del nas i de les dos mans així, damunt del pit... I els van trobar allí. No els trobaven, no els trobaven... I a l'endemà van trobar un mocador blanc, que era d'ella, i els van trobar dalt de la roca, morts tots dos. Romeo y Julieta de Tivissa.

C: Se sap com se van matar o...?

I: Se van enverinar. Hi han herbes molt bones per esta comarca, per enverinar i... ${ }^{26}$

En aquest relat, per bé que els protagonistes són un home i una dona, destaca el fet que el personatge de Margarida no és un personatge passiu, sinó amb iniciativa pròpia, atès que es nega a casar-se amb qui han decidit els seus pares (un senyor de la vila) i decideix fugir amb Alí. Finalment, tos dos, Margarida i Alí, decideixen acabar amb la pròpia vida abans que ser obligats a viure separats. Es pot observar que el rol de la protagonista és el d'una dona valenta i decidida que agafa les regnes del seu destí, malgrat que això comporti el suïcidi. ${ }^{27}$

Continuant amb el rol de dona decidida amb determinació per evitar allò que li és imposat, i que opta pel suïcidi si cal, és ben conegut al Priorat i al Camp de Tarragona «El salt de la Reina Mora», de Siurana. Aquest relat explica el nom rebut per una roca d'un espadat molt conegut de l'encimbellada població de Siurana, darrer reducte musulmà de la reconquesta cristiana a Catalunya.

El salt de la reina mora es remunta a l'any I553 quan va haver-hi l'assalt dels cristians a l'últim reducte sarraí al castell de Siurana. Aleshores, després de vàrios setges, els cristians no van aconseguir treure els sarraïns del castell. Finalment, va haver-hi un acorralament total al que és l'inexpugnable castell de Siurana perquè era una fortalesa natural. Aleshores, doncs, van aprofitar un moment que no hi havia el rei i un cop van poder accedir-hi, la reina mora es va trobar en una situació de vida o mort que era: o bé entregar-se als cristians, amb la conseqüència de patir el que li poguessin fer, o bé que la poguessin convertir al catolicisme. I aleshores va decidir morir. I el que va fer és córrer amb el seu cavall blanc (que tenia un cavall blanc molt bonic). Va córrer cap al penya-segat i el que passa és que el cavall blanc, quan va arribar al penya-segat, se'n va adonar que allí no hi havia més per seguir, no? I llavòrens va frenar de cop i va clavar la petjada a la pedra. Ella va saltar i el cavall darrere, evidentment. I així els cristians es van quedar sense la reina mora. La reina mora va triar un altre destí. I això és

26 Informant Montse Bladé Bru; versió recollida el dia II de juliol de 20I7, a Tivissa.

27 El fet que el nom del tormo sigui «de la Margarida» i no pas «d'Alí i Margarida», com seria d'esperar, cal no lligar-lo a un major protagonisme d'ella, sinó, com explica la informant, al simple efecte de la pareidolia, la il-lusió visual falsejada per la fantasia, a través de la qual a les imatges s'atribueixen significats fantàstics (als núvols, formes humanes o d'animals; a una taca, el retrat d'una cara, etc.). 
el salt de la reina mora. D’aquí ve la tradició, no? Que és l'última persona que va quedar aquí després de la conquesta dels cristians a l'últim reducte sarraí a Catalunya (Oriol 2005: 24). ${ }^{28}$

En aquest relat es presenta una heroïna que resisteix una invasió forana, però que, en veure's perduda, i a mercè de l'enemic, opta per treure's la vida d'una manera espectacular.

El cas de «Galbor, o Galbors, d'Entença» és semblant al de la reina mora. S'hi presenta una heroïna que resisteix una molt forta amenaça i un perill evident, dels quals, a diferència del personatge anterior, surt victoriosa i sense la necessitat de perdre la vida. L'informant explica que el relat naix de les tres diferents interpretacions d'uns documents dipositats a l'Archivo Ducal de Medinaceli que van fer tres figures importants de la Ribera d'Ebre: Artur Bladé i Desumvila, Artur Cot i Carmel Biarnés. Aquesta informació permet deduir que l'origen d'aquesta tradició explicativa podria ser una llegenda històrica que s'ha oralitzat.

La història està barrejada. A mi m'agrada molt dir que la història està entre la veritat i la mentida. La d'ara, en este moment. Segons en quin polític escoltem està dient una cosa i a l'altre l'altra. I acaba de passar, no? És a dir, tu has vist una cosa i cadascú l'ha vist d'una manera. Ara imagine't la de fa dos, tres, quatre o cinc-cents anys... o mil. evidentment, ha arribat a nosaltres a partir de uns cronistes i, quan s'ha traduït aquell document, eh... Lo de la Galbor d'Entença, els tres escritors riberencs, Artur Cot, Artur Bladé i Carmel Biarnés escriuen la mateixa història i l'escriuen diferent. Lo bo és que sempre, la Galbor d'Entença pot amb el setge. És a dir, sempre la heroïna, la dona, la Galbor... Lo que passe és que al montatge... per tant, està entre la veritat i la mentida. Per què? Perquè cada un ha llegit la crònica escrita que hi ha, me semble que és a Medinaceli, a Sevilla, l'ha traduït a la seva manera. És veritat, però, quina veritat? Hi ha hagut més gent que l'ha traduït i ha posat una altra història. La del Carmel Biarnés, a mi, m’agrada molt, perquè inventa molt, inventava molt ... [riu]... a la seva manera traduïa molt bé lo que podia haver passat en aquesta guerra intercomarcal, que va ser dura, cruenta; com totes les guerres, té, tenia un significat: diners, com sempre, com totes les guerres. O sigui, fa una colla d'anys, ja s'estava lutxant per diners, entre Templers i Entença, i Montcades per l'altre costat. Al mig dels territoris que el rei dóna, que eren los Entença, que eren una família poderosa del moment, que arribava fins a Prades en tot lo territori de Tivissa. I, al ser, un centre neuràlgic i un castell (un castellet petit, però en una població emmurallada), ve a conquerir este castell, els Templers i els Montcada era, ffffffttt, una il.lusió.

$[\ldots]$

Lo seu home, Berenguer d'Entença havia anat a la guerra a ajudar el rei, amb els fills, i Móra, amurallada,... (De fet el castell de Móra no ha estat mai un castell defensiu, perquè quedava dins d'un circuit emmurallat. Sí era la punta d'una de les muralles i gairebé sempre lo trobes més com a lloc de residència que com a lloc defensiu, perquè si estava dins d'un re-

28 Informant: Roger Felip Ibars, propietari del restaurant Siurana, nascut a Barcelona l'any I972; l'enregistrament es va realitzar a Siurana de Prades el 25-OI-2003. 
cinte emmurallat, ja s'entén això, no?). Et trobes que el poble havia quedat en crios i gent gran, lo qual si pensem que la mitjana d'edat d'aquell temps era 35 anys, no eren tan grans, no? Aleshores, els Montcades, els Montcada i els Templers, sobretot, reconduïen la gent paca Ascó des de Camposines... o sigue si anaven a creuar el riu per Ascó, no pagaven, però si baixaven a Móra, pagaven. Aleshores, pagaven dos vegades: per creuar la barca a Móra i per passar de Camposines aquí. I això se suposava que per a les arques de... Aleshores aprofiten l'absència del baró per a atacar Móra. Després de tres mesos de setge, no van poder conquerir el castell, bueno, lo poble; i damunt se'ls havia posat la verma, damunt d'ells, i, per tant, els hòmens havien d'anar a vermar. I això és important per a fer la guerra. En aquell moment l'heroïna, Galbor, va passar per damunt de tots uns Templers i tots uns Montcada, amb un exèrcit més que minvat i amb un refugi com podia ser Móra emmurallada. No hi va haver més destrossa. Ella va quedar com una heroïna i les rendes que després el rei va fer pagar tant a uns com als altres, les pèrdues van ser més que nombroses, perquè en la retirada, els Templers van tallar tots los pins des de Móra a Tivissa. Aleshores, diuen que els hi va fer pagar I per Ioo, eeehh, Ioo per I. ${ }^{29}$

El fet és que Berenguer d'Entença va anar a fer costat al rei en una guerra, juntament amb els seus fills i el gruix dels seus hòmens, de manera que al castell de Móra només hi van quedar dones, vells i criatures. Els Montcada i els Templers, enemics dels d'Entença, van aprofitar aquesta desprotecció per posar setge al castell, però no van comptar amb el fet que la muller del baró, Galbor d'Entença, agafaria les regnes de la situació i organitzaria una resistència ben efectiva. Galbor va enviar un missatge a Berenguer per dir-li que aguantaria el setge fins que ell tornés. I així va ser, van aguantar tres mesos, i la població de Móra no va haver de patir cap damnatge. Aquesta història és ben coneguda per tota la gent de Móra i n'és motiu d'orgull, especialment, entre les dones. Dibuixa una protagonista amb decisió, valenta, que pren el relleu al marit absent i organitza una població civil ben migrada per resistir un setge davant d'un exèrcit armat, nombrós i potent.

\subsection{Amonestaments}

Un altre rol femení negatiu apareix a Gandesa, amb el personatge de la Serena. La Serena de Pàndols és un monstre mig dona i mig moixó que habitava a les serres de Pàndols i de Cavalls, a la Terra Alta, i atacava els hòmens. Joan Perucho ja escriu sobre aquest personatge arran de la seua estada com a jutge a Gandesa l'any I957, on afirma que ja hi ha notícia de la Çerena, «bèstia fantàstica, mig ocell i mig dona», l'any II92, quan Miró de Cròcia —un dels cinc misteriosos personatges als quals fa referència la carta de població de Gandesa- se la va trobar a la serra (Perucho 2003: 55).

De fet, la Serena també apareix descrita en els bestiaris antics catalans, Saverio Panunzio en reprodueix un text a Bestiaris. El text prové de diversos manuscrits de bestiaris en català que són versions del Bestiario Toscano.

29 L'informant és Santi Alfonso Falcó, de Móra d'Ebre. Relat recollit a l'agost de 20I7, a l'Aubadera, a Móra d'Ebre. 
La Çerena si és una creatura molt meravellosa, e ha-n’hi de tres maneres: la una és mig peix e mig fembra, l'altra és mig oçel e mig fembra, l'altra és mig cavall e mig fembra [...] E aquella que és mig alçell e mig fembra, si fa un so d'arpa tant dolç que tot hom lo va oyr volonters, tant fins que s'i és adormit; e atressí aquesta çerena lo vén alciure (Panunzio I963: 79-80).

Però la Serena que perdura en l'actualitat, en el record dels més grans de la capital de la Terra Alta, és el d'una Serena amb l'única funció d'amonestament a infants. Els informants expliquen que era el personatge amb què els adults els amenaçaven si feien alguna cosa incorrecta o en deixaven de fer alguna de correcta:

I: Sabíem que ere lo que havíem sentit dir, però qui va ser l'inventor de què ere això? I, claro, pos, mos semblave que era un monstru que mos prendrie. Era algú que mos pendrie i, clar, pos, a sopar. O quan se feie de nit, paca casa, perquè ui...

C: Clar, vindrà la Serena...

I: I si no, venia el pare amb l'escorretja. Vull dir, també... Tot lligave. Però la por era això: vindrà la Serena i et pendrà.

C: I us la descrivien com ere, o no?

I: No... ja ho sabíem, Bueno, saps que passe?, que t'ho explicaven per a fer-te por, de vegades... jo me’n recordo que alguna vegada: «Sí, perquè, ai, té unes ales com d'aquí a la sala», o «té un bec que fa així, igual que una àguila gran». I, quan ets petit, pos allò, los ulls... ostres... ostres... «Té unes ales... i después sap molta solfa, toque una música que encante. I, quan te té encantat, te pren!» I, clar, aquella por, los xiquets. T’explico, també, una mica de ficció i, no? Perquè... quan se parlava de la Serena ere per a que tu conservessis aquella por. Perquè quan te deien: Mira que vindrà la Serena... I ere allò que sempre estaves... ${ }^{30}$

Els informants relaten, també, que la Serena tenia la casa al puig Cavaller, un cim de la serra de Pàndols que es veu des de la vila, i que en sortia les nits de lluna plena i tombava per les serres de Pàndols i Cavalls, pel barranc de l'Infern, per les Coves, per la font del Canteret, la font i el povet del Gravet, la font de l'Heure [sic], la Fontcalda...

Sembla que la transmissió intergeneracional d'aquest personatge i la seua funció es va perdre a Gandesa cap als anys setanta del segle passat. Sortosament, va ser recuperat volgudament cap al 2005, quan es va crear el grup cultural La Serena, que, entre altres accions, va convocar un concurs de dibuix adreçat a escolars gandesans sobre el personatge. D'aquest concurs en va sortir el dibuix guanyador que va inspirar la imatge de la Serena feta de ferro forjat que llu al carrer de Miravet de Gandesa. Allí mateix, també hi ha una placa explicativa del mite, col-locada per l'Ajuntament de la vila, de manera que s'ha convertit en un punt de referència per a qualsevol gandesà. Així mateix, en l'actualitat, la Serena, a Gandesa, ha perdut també aquest caràcter ancestral d'amonestament i ha passat a incorporar-se a l'escola com un element de lleure. Fins i tot se n'ha publicat un conte infantil que és conegut per tota la població (Cid 2013).

3o Rafel Jornet Escuder, de Gandesa, i Maria Espina Niella Clua, de Calaceit, matrimoni que viu a Gandesa. Gravació feta el 2 d'agost de 2017 a Gandesa. 


\section{Conclusions}

En aquest article s'han tractat disset relats i dues altres referències (la cova de les Bruixes de Riba-roja i el carrer de les Bruixes de Flix) lligats a topònims de les comarques de la Ribera d'Ebre, la Terra Alta i el Priorat, en els quals les dones, majoritàriament protagonistes, han assumit un ventall de rols diversos. Aquests rols es podrien resumir de la manera següent.

La dona dolenta, perillosa i temuda és reflectida en la figura de la bruixa i del mite de la Serena. El paper de la bruixa apareix en sis relats: «La roca dels Bruixes» (Ascó), «La roca de la Bruixeta» (la Torre de l'Espanyol) i «La roca del Cap del Pla» (Vinebre), «La carrasca de Guixo» (Tivissa) i «La Miloquera» (Marçà), i en dos topònims: la cova de les Bruixes (Riba-roja d'Ebre) i el carrer de les Bruixes (Flix). El personatge de la Serena es recull en el relat de «La Serena de Pàndols» (Gandesa).

La dona que té un paper passiu i es dedica a la reproducció de l'espècie apareix en dos relats: «Les Cabreres» (Tivissa) i «La cova del Moro» (Arnes). Per bé que també trobem la referència sexual de «Lo forat de la Donzella» (Bot).

La dona que és víctima d'agressions sexuals apareix als relats «La cova del Moro» (Arnes), «Lo salt del Flare» (Rasquera) i a «Miss Amaroi» (Tivissa), en el personatge que li dona nom.

El paper de la prostituta apareix en el relat de «La cova de la Porca» (Móra d'Ebre).

La dona activa, valenta i agosarada que acaba la seua comesa amb èxit es recull a «Galbor d'Entença» (Móra d'Ebre), i a «Miss Amaroi», en el personatge d'Amantdell. Als relats «Lo tormo de la Margarida» $\mathrm{i}$ «Lo salt de la Reina Mora» (Siurana) hi apareixen dones valentes i decidides, però que no sobreviuen, sinó que se suïciden.

Així, doncs, la valoració quantitativa final entre rols amb característiques positives i rols amb característiques negatives és força evident. El plat de la balança de les dones exemplars és ben buit al costat de les dones «dolentes», o passives. 


\section{Referències bibliogràfiques}

BALDAQUí, Josep M. (I997): «Les llegendes toponímiques en l'obra de Francesc Martínez i Martínez». Dins XXI Col-loqui de la Societat d'Onomàstica. Paiporta: Denes, p. 45-55.

CABRÉ, Dolors (I974): Riba-roja d'Ebre i el seu terme municipal: geografia, història, economia, onomàstica. Tarragona: Llibreria Guàrdias.

CID, Àngels (20I5): La Serena. Gandesa: Ajuntament de Gandesa.

Coromines, Joan (I989-I997): Onomasticon Cataloniae. Els noms de lloc i els de persona de totes les terres de llengua catalana. 8 volums. Barcelona: Curial.

Cortés, Antoni (200I): «La Donzella del Forat». Dins Fets i contes a Bot. Bot: edició de l'autor, p. 27-33.

Gomis, Cels (I996): La bruixa catalana.za edició. Barcelona: Alta Fulla.

Jorgensen, Jeana (2008): «Gender». Dins Donald HAASE (ed.): The Greenwood Encyclopedia of Folktales \& Fairy Tales. Connecticut/Londres: Greenwood Press, p. $402-404$.

MALlORQUí, Elvis (coord.) (2006): Toponímia, paisatge i cultura. Els noms de lloc des de la lingüística, la geografia i la història. Girona: Associació d'Història Rural de les Comarques Gironines / Centre de Recerca d'Història Rural de la Universitat de Girona / Documenta Universitaria.

ORIOL, Carme (2002): Introducció a l'etnopoètica: teoria i formes del folklore en la cultura catalana. Valls: Cossetània.

- (2005): El patrimoni oral a les comarques de Tarragona. Relats tradicionals. Tarragona: Diputació de Tarragona.

—(20I3): «L'estudi de la literatura popular catalana des d'una perspectiva de gènere». Dins Montserrat BACARDí; Francesc FogueT; Enric GALlÉN (eds.): La literatura catalana contemporània: intertextos, influències i relacions. Barcelona: Institut d'Estudis Catalans / Universitat Autònoma de Barcelona, p. I97-209.

PAnUnZIO, Saverio (I963): «XVII de la Serena». Dins Bestiaris. Barcelona: Barcino, p. 79-80.

Perucho, Joan (2003): Fulls de fronteres. Entre Gandesa i Alcanyís. Alcanyís: Centro de Estudios Bajoaragoneses.

VEÀ, Sílvia (20I7): Onomàstica de Vinebre. Barcelona: Institut d’Estudis Catalans. 